\title{
Effect of feeding velvet beans (Mucuna pruriens) on the lipid profile of broiler chickens
}

\author{
Jayaweera, T.S.P. ${ }^{1}$, Cyril, H.W. ${ }^{2}$, Samarasinghe, K ${ }^{2}$, Ruwandeepika, H.A.D. ${ }^{1}$, \\ Wickramanayake, D.D ${ }^{1}$. and Thotawaththe, T.S.J. ${ }^{1}$ \\ ${ }^{1}$ Department of Livestock Production, Faculty of Agricultural Sciences, \\ Sabaragamuwa University of Sri Lanka, Belihuloya, Sri Lanka. \\ ${ }^{2}$ Department of Animal Science, Faculty of Agriculture, University of Peradeniya, \\ Sri Lanka.
}

\begin{abstract}
The effect of feeding velvet bean (Mucuna pruriens) meal on the lipid profile in broilers was investigated. Two hundred, 14 days old broiler chicks were randomly allocated to five dietary treatments in a completely randomized design and feeding continued for four weeks. Maize and soybean meal based control feed and four test diets prepared from the control feed by incorporating velvet beans at 10, 15, 20 and $25 \%$ levels served as five dietary treatments. Feed intake was unaffected by velvet beans. Serum total cholesterol level was lowered by $9.5,9.7,15$ and $16 \%$ in birds fed with $10,15,20$ and $25 \%$ velvet bean diets. Birds fed $25 \%$ VB diet showed an increase in HDL level by $8 \%$. LDL level was lowered by $43.1,36.5,25$ and $23.4 \%$, respectively in birds fed with $25,20,15$ and $10 \%$ velvet beans. Velvet beans reduced the serum triglyceride levels. Results suggest that Velvet beans contain a strong cholesterol lowering effect in broilers.
\end{abstract}

Key words: Velvet beans, broilers, cholesterol

\section{Introduction}

Meat and other animal products can play a significant role in alleviating the nutritional status of the people. Meat is an excellent source of high-quality and readily digestible protein. They are also good sources of micronutrients (Layrisse et al., 1990; Bender, 1992).

Presence of cholesterol in meat and other animal originated foods is a main factor discouraging the consumption of such foods. Now a days, people are more concern about the nutritional quality and related possible health hazards of dietary components. Most of the people restrict eating meat due to the fear of having high cholesterol content in meat (Abeywardena, 2003). This situation has led to missing of an excellent source of nutrients in the diet thus causing protein malnutrition in Sri Lanka.

Therefore it is a timely need to reveal measures to produce meat with low cholesterol level as it will make meat more attractive to the people and hence meat consumption could be increased. It then will have a significant effect to reduce the protein malnutrition problem as well as to reduce the health hazards due to consumption of meat. One way of lowering meat cholesterol is to incorporate cholesterol reducing factors into the diets of meat producing animals.

Some of the studies done on velvet beans (Mucuna pruriens) have indicated a cholesterol lowering effect of velvet beans (Carew, 1998a; Del Carmen, 1999; lauk, 1989 and Carew, 2003). However, it has not been investigated in detail so far.

(C) 2007 Sabaragamuwa University Journal, vol 7, no.1, pp 78-85 
Velvet bean is used as a cover crop, human food or as an animal feed in many areas of the world. It is found in some parts of Sri Lanka and consumed by local people. Though it can be grown very easily under the climatic conditions of the country (Ravindran, 1988), this valuable crop is not yet properly exploited in Sri Lanka. People who are traditionally consuming velvet beans have claimed for various medicinal properties of it. Therefore the present study was conducted to investigate whether velvet beans possess any cholesterol lowering effect and whether it can be used as a protein feed for broiler chickens.

\section{Materials and methods}

The study was conducted in the Sabaragamuwa University of Sri Lanka. Two hundred unsexed day-old broiler chicks of Hubbard strain were obtained from the hatchery of National Livestock Development Board, Miriswatta Farm. They were commonly brooded for 14 days in a floor brooder and fed on a commercial broiler starter feed ad libitum during brooding. On the $14^{\text {th }}$ day, chicks were divided into 20 groups of 10 and transferred to 20 deep litter pens. Five dietary treatments were assigned to 20 groups with 4 replicates per treatment according to a complete randomized design (CRD).

Dried, velvet bean seeds were collected from shops and farms in Balangoda, Pelmadulla, Godakawela and Ratnapura areas. The whole beans were heated by keeping in a laboratory oven at $130{ }^{\circ} \mathrm{C}$ for 30 minutes as described by Carew et al. (2003). Seeds were then ground using a laboratory mill to pass through a $0.25 \mathrm{~mm}$ screen and stored in airtight polythene bags at room temperature until used for then trial. Samples of velvet beans were subjected to proximate analysis and the reference value of $2370 \mathrm{kcal} / \mathrm{kg}$ (Del Carmen et al., 1999) was used as the metabolizable energy of velvet bean. The reference values were also used for amino acids and mineral contents of velvet beans (Del Carmen et al., 1999) in formulating test diets.

Table 1. Composition of experimental diets

\begin{tabular}{|l|c|c|c|c|c|}
\hline & \multicolumn{5}{|c|}{ Level of velvet bean in the diet } \\
\hline \multicolumn{1}{|c|}{ Ingredient (\%) } & $\mathbf{0 \%}$ & $\mathbf{1 0 \%}$ & $\mathbf{1 5 \%}$ & $\mathbf{2 0 \%}$ & $\mathbf{2 5 \%}$ \\
\hline Rice polish & 21.5 & 21.3 & 23 & 24 & 24 \\
\hline Maize & 38 & 35.3 & 31 & 27.7 & 24 \\
\hline Fish meal & 4 & 4 & 4 & 4.4 & 5.4 \\
\hline Soybean meal & 20.3 & 19.4 & 18.5 & 17 & 14 \\
\hline Coconut Poonac & 10 & 3.7 & 1.9 & 0 & 0 \\
\hline Velvet beans & 0 & 10 & 15 & 20 & 25 \\
\hline Calcium carbonate & 1.8 & 1.9 & 1.9 & 1.9 & 1.9 \\
\hline $\begin{array}{l}\text { Di-calcium } \\
\text { phosphate(DCP) }\end{array}$ & 0.7 & 0.7 & 0.7 & 0.7 & 0.7 \\
\hline Lysine HCl & 0.05 & 0.05 & 0.05 & 0.05 & 0.05 \\
\hline DL-Met & 0.15 & 0.15 & 0.15 & 0.15 & 0.15 \\
\hline Coconut oil & 3 & 3 & 3.3 & 3.6 & 4.3 \\
\hline
\end{tabular}




\begin{tabular}{|c|c|c|c|c|c|}
\hline Salt & 0.25 & 0.25 & 0.25 & 0.25 & 0.25 \\
\hline $\begin{array}{l}\text { Vitamin mineral } \\
\text { premix }\end{array}$ & 0.25 & 0.25 & 0.25 & 0.25 & 0.25 \\
\hline \multicolumn{6}{|c|}{$\frac{\text { Calculated nutrient levels (per }}{\underline{\mathrm{kg}} \text { ): }}$} \\
\hline $\begin{array}{l}\text { Metabolizable } \\
\text { energy (MJ) } \\
\text { Crude protein(q) }\end{array}$ & $\begin{array}{r}13.33 \\
200.32\end{array}$ & $\begin{array}{r}13.32 \\
200.18\end{array}$ & $\begin{array}{r}13.31 \\
200.22\end{array}$ & $\begin{array}{c}13.32 \\
200.32\end{array}$ & $\begin{array}{c}13.32 \\
200.24\end{array}$ \\
\hline
\end{tabular}

A control diet based on maize and soybean meal was prepared to contain all the nutrients required by broiler finishers as recommended by NRC (1994). Four test diets were prepared by incorporating $10 \%, 15 \%, 20 \%$ and $25 \%$ velvet beans respectively to the control diet at the expense of soybean meal and coconut poonac (Table 1). Amounts of other ingredients were slightly adjusted to make the rations isoenergetic and isoproteic. Experimental diets in mash form were offered to birds ad libitum during 4 weeks. Birds had free access to drinking water all the time.

Group feed intake was recorded daily. Blood samples were collected from five randomly selected birds from each group on $21^{\text {st }}, 28^{\text {th }}, 35^{\text {th }}$ days and at slaughter. They were collected by venupuncturing the wing vein of birds. Blood was collected to vacutainers with no additives for serum separation. The samples were stored at $-20^{\circ} \mathrm{C}$ until further analysis. Birds were slaughtered on $42^{\text {nd }}$ day by severing the jugular vein. Meat samples were obtained from the breast muscle and fat samples were obtained from the abdominal fat pad of three randomly selected eviscerated carcasses from each replicate group. They were stored in sealed, labelled polythene bags at $-20^{\circ} \mathrm{C}$ until further analysis. Blood samples at every week and meat and fat samples were subjected tolipid profile analysis (Total cholesterol, high density lipoproteins (HDL), low density lipoproteins (LDL) and Triglycerides) by enzymatic diagnostic kits (Diasys diagnostic kits). The cholesterol determination for each sample was made using the extraction procedure of Fisher and Leveille (1957). The cholesterol estimation was carried out according to the Liberman-Burchard method as described by Sabir et al. (2003).

Data were subjected to analysis of variance (ANOVA) with $p<0.05$ considered significant (SAS/SPSS, 2000). Duncan's Multiple Range Test (DMRT) (Duncan, $1955)$ was used to compare mean values.

\section{Results And Discussion}

The initial body weight of birds was similar in all treatment groups. The average feed intake during the trial period varied from 117.8 to $119.3 \mathrm{~g} / \mathrm{head} /$ day without a significant difference $(p<0.05)$ between treatments. Del Carmen et al. (1999) and Carew et al. (2003) found significantly reduced feed intake when raw velvet beans were introduced to broiler diets and it was partially but significantly reversed when velvet beans were heated before feeding indicating the antipalatability factor was removed by heat treatment. Iyayi and Taiwo (2003) also found that incorporating heated velvet beans up to $33.3 \%$ level do not reduce the feed intake of broilers. Since heat treated velvet beans were used in the present 
study, similar feed intake observed in all treatment groups agrees with the previous observations of Del Carmen et al. (1999), Carew et al. (2003) and lyayi and Taiwo (2003).

\section{Serum lipid profile}

There was a significant negative linear correlation between the level of velvet beans in the diet and total cholesterol $(r=0.97)$, LDL $(r=0.97)$ and triglycerides $(r=0.97)$ concentration in serum. Serum HDL had a positive linear correlation ( $r$ $=0.77$ ). As shown in Table 3 , serum total cholesterol concentration was significantly lower $(p<0.05)$ in birds who received velvet bean diets compared to the control group. Velvet beans at $20 \%$ and $25 \%$ reduced the serum total cholesterol by $15 \%$ and $16 \%$, respectively. Total cholesterol was reduced by $9.6 \%$ up to $15 \%$ velvet beans in the diet. Similar cholesterol depressing effects due to feeding velvet beans in broilers have been observed by Carew et al. (1998a, 2002 and 2003). This is also in agreement with results reported on rats by Pant et al. (1968) and lauk et al. (1989). Various effects on concentrations of insulin and glucagons (Beynen et al., 1990; Ham et al., 1993; Barath et al., 1990; Forsythe, 1986; Sanchez and Hubbard, 1991 and Scholz- Ahrens et al., 1990) have been reported due to feeding soy protein. Similar hormonal changes have been reported in rats after feeding velvet beans (Pant et al., 1968; lauk et al., 1989). Sanchez and Hubbard (1991) found that the lower lysine: arginine ratio of soy protein decreases the secretion of insulin and increases the secretion of glucagon. As velvet bean also contains a similar lysine:arginine ratio, the same changes in insulin and glucagons in birds fed velvet beans can be expected. It is therefore suggested that lowering of insulin: glucagon ratio may have reduced cholesterol synthesis in birds and responsible for the hypocholesterolemic effect of velvet bean. Nagata et al. (1982) and Sugano et al. (1990) observed reduced serum cholesterol levels in rats fed soy proteins due to increased faecal steroid excretion, in particular bile acids. They found that this effect was partially caused by the binding of bile acids to soybean saponins. Similar mechanism can be expected in animals fed velvet beans, due to availability of saponins (Bressani, 2002). 
Table 3. Effect of dietary velvet beans on serum lipid profile and total cholesterol in meat and abdominal fat of broiler chickens (Mean $\pm \mathrm{SE}$ ).

\begin{tabular}{|c|c|c|c|c|c|}
\hline \multirow{2}{*}{$\begin{array}{c}\text { Lipid fraction } \\
\mathrm{mg} / \mathrm{dl} \\
\end{array}$} & \multicolumn{5}{|c|}{ Level of velvet beans in the diet } \\
\hline & $\mathbf{0 \%}$ & $10 \%$ & $15 \%$ & $20 \%$ & $25 \%$ \\
\hline \multicolumn{6}{|l|}{ Serum lipids: } \\
\hline Total cholesterol & $162.0 \pm 4.34^{\mathrm{c}}$ & $146.6 \pm 6.21^{\mathrm{b}}$ & $146.7 \pm 2.34^{\mathrm{b}}$ & $138.6 \pm 4.75^{\mathrm{a}}$ & $136.3 \pm 5.37^{\mathrm{a}}$ \\
\hline HDL & $70.9 \pm 3.98^{\mathrm{a}}$ & $72.1 \pm 4.75^{\mathrm{b}}$ & $72.8 \pm 2.52^{\mathrm{b}}$ & $74.2 \pm 6.38^{\mathrm{c}}$ & $76.6 \pm 5.72^{\mathrm{c}}$ \\
\hline LDL & $59.7 \pm 2.29^{\mathrm{c}}$ & $45.8 \pm 3.15^{\mathrm{b}}$ & $44.8 \pm 1.75^{\mathrm{b}}$ & $37.9 \pm 4.13^{\mathrm{a}}$ & $33.9 \pm 3.65^{\mathrm{a}}$ \\
\hline HDL/LDL ratio & $1.2 \pm 0.53^{\mathrm{a}}$ & $1.6 \pm 0.59^{\mathrm{b}}$ & $1.6 \pm 1.87^{\mathrm{b}}$ & $2.0 \pm 1.12^{\mathrm{c}}$ & $2.3 \pm 0.95^{\mathrm{c}}$ \\
\hline Triglycerides & $160.4 \pm 14.34^{\mathrm{b}}$ & $144.1 \pm 20.45^{\mathrm{a}}$ & $141.5 \pm 17.83^{\mathrm{a}}$ & $132.8 \pm 15.67^{\mathrm{a}}$ & $\begin{array}{l}130.0 \pm 13.33 \\
\mathrm{a}\end{array}$ \\
\hline \multicolumn{6}{|c|}{ Total Cholesterol(mg/g) in: } \\
\hline breast muscle & $0.59 \pm 0.15^{\mathrm{c}}$ & $0.57 \pm 0.65^{b}$ & $0.56 \pm 0.45^{b}$ & $0.49 \pm 0.75^{\mathrm{a}}$ & $0.47 \pm 0.83^{\mathrm{a}}$ \\
\hline abdominal fat & $0.90 \pm 0.16^{\mathrm{c}}$ & $0.87 \pm 0.71^{b}$ & $0.85 \pm 0.23^{b}$ & $0.80 \pm 0.57^{\mathrm{a}}$ & $0.79 \pm 0.71^{\mathrm{a}}$ \\
\hline
\end{tabular}

$a, b, c$ : Means with different superscripts in a row are significantly different $(p<0.05)$.

All the birds that received velvet bean diets had significantly lower $(p<0.05)$ levels of LDL concentrations compared to the control group and it was lowered by $43.1 \%, 36.5 \%, 25 \%$ and $23.4 \%$ respectively in birds fed with $25 \%, 20 \%, 15 \%$ and $10 \%$ velvet beans. Huff and Carrol (1980), Kim et al. (1980), Nagata et al. (1982), Thanaka et al. (1984), Van der Meer et al. (1988), Beynen et al. (1990) and Kirk et al.(1998) revealed that isoflavones in soy protein increase LDL receptor activity in animals and as a result, total and LDL cholesterol levels get decreased. Considering the same content of isoflavones in soybean and velvet beans (Bressani, 2002), similar mechanism can be expected with velvet beans too.

The serum HDL levels in birds fed with 20 and $25 \%$ of velvet beans were significantly higher $(p<0.05)$ by $4.5 \%$ and $8 \%$ respectively as compared to the control group. $15 \%$ and $10 \%$ velvet bean diets increased the HDL level $(p<0.05)$ by $2.6 \%$ and $1.7 \%$, respectively compared to the control. The serum triglyceride concentration was lower $(p<0.05)$ in all the birds fed velvet beans compared to the control group. But there was no significant $(p<0.05)$ difference in serum triglyceride concentration among birds that received different levels of velvet beans. Khosla et al. (1991) and Lovati et al.(1991 and 1992) reported that soy protein increases the removal of very low density lipoproteins (VLDL) from the blood. Composition of Velvet bean is also similar to that of soy protein (Carew et al., 2002). VLDL is the vehicles of transport of triglycerides in the body. Therefore removal of VLDL from the blood causes a reduction in triglyceride content as well. However according to the results, it is clear that the triglyceride lowering effect of velvet beans is similar up to $25 \%$ inclusion in the diet. 


\section{Lipid profile in meat and fat}

The cholesterol content in broiler breast muscle was significantly lower $(p<0.05)$ in birds fed with velvet bean diets than those on the control diet (Table 3 ). Compared to the control group, the total cholesterol contents in broiler meat of birds given $10 \%, 15 \%, 20 \%$ and $25 \%$ velvet beans were reduced by $4.1,4.8,17$ and $20 \%$, respectively showing a negative linear correlation $(r=0.90)$ between the two factors. This clearly shows the increasing hypocholesterolemic effect of velvet beans with increasing level of inclusion in the diet. The same pattern was observed in the cholesterol content of abdominal fat too. This effect could be a result of reduced cholesterol synthesis in the body due to hormonal changes caused by velvet beans.

\section{Conclusions}

It is concluded that heated velvet beans can be used as a source of protein in broiler diets up to $15 \%$ without affecting the feed intake. Velvet beans posses a strong cholesterol lowering effect which seems to be heat tolerant. It reduces total cholesterol, LDL and triglycerides while increasing HDL levels in broilers. This medicinal property of velvet beans will be of great interest to meat producers and consumers. Further studies are needed to test this effect on other meat producing animals and directly on humans.

\section{Acknowledgement}

This investigation received financial support from the Sabaragamuwa University of Sri Lanka (Grant No.SUSL/RG/2006/04). Authors wish to appreciate the assistance of the technical staff at Animal science laboratory, University of Peradeniya. The encouragement and support of Mr. G. Weerakkody, Mr.A.M.P.Attanayake, Mr. N. Dissanayake and Ms. Kumudumala Dissanayake of the Faculty of Agricultural Sciences, Sabaragamuwa University of Sri Lanka is highly appreciated.

\section{References}

Abeywardena, M.Y. 2003. Dietary fats, carbohydrates and vascular disease: Sri Lankan perspectives. Atherosclerosis, 171:157-161.

Barath, C. A., Scholz-Ahrens, K. E., Pfeuffer, M. and Hotze, A. 1990. Response of hormones and lipid metabolism to different dietary proteins. Monogr.Atheroscler.16: 25-35.

Bender, A. 1992. Meat and meat products in human nutrition in developing countries. Food and Nutrition Paper, no.53, Food Policy and Nutrition Division, FAO, 1-88.

Beynen, A. C. 1990. Comparison of the mechanism proposed to explain the hypocholesterolemic effect of soybean protein versus casein in experimental animals. J. Nut. Sci. Vitaminol.36:87- 93.

Bressani, R. 2002. Factors influencing nutritive value in food grain legumes: Mucuna compared to other grain legumes. In: Food and Feed from Mucuna: Current Uses and the Way Forward: Flores, B. M., Eilittä, M., Myhrman, R.,

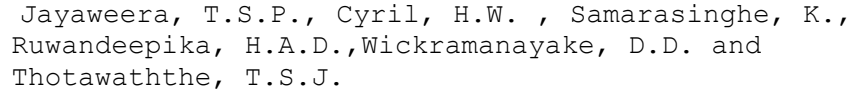


Carew, L.B., and Carsky, R.J. (Eds). Proceedings of an International Workshop held in Tegucigalpa, Honduras, April 2000, 164-188.

Carew, L.B., Alster, F.A. and Gernat, A.G. 1998a. Blood chemistry including cholesterol, glucose and thyroid hormones of broilers fed raw velvet beans (Mucuna pruriens). J.Anim. Sci. 76 (2): 82-90.

Carew, L.B., Hardy, D., Weis, J., Alster, F.A., Mischler, S.A., Gernat, A.G. and Zakrzewska, E.I. (2003). Heating Raw Velvet Beans (Mucuna pruriens) Revers Some Antinutritional Effects on Organ Growth, Blood Chemistry, and Organ Histology in Growing Chickens. Trop. Subtrop. Agroecosys. 1: 267 - 275.

Carew, L.B., Valverde, M.T., Zakrzewska, E.I., Alster, F.A. and Gernat, A.G. (2002). Raw velvet beans (Mucuna pruriens) and L-dopa have differing effects on organ growth and blood chemistry when fed to chickens. pp. 272-287. In: Food and Feed from Mucuna: Current Uses and the Way Forward: Flores, B. M., Eilittä, M., Myhrman, R., Carew, L.B., and Carsky, R.J. (Ed). Proceedings of an International Workshop held in Tegucigalpa, Honduras, April 2000.

Del Carmen, J., Gernat, A.G., Myhrman, R. and Carew, L.B. (1999). Evaluation of raw and heated velvet beans (Mucuna pruriens) as feed ingredients for broilers. Poult. Sci.78: 866- 872.

Duncan, D.B. 1955. Multiple range and multiple F- test. Biomet. 11: 1-42.

Forsythe, W. A. (1986). Comparison of dietary casein or soy protein effects on plasma lipids and hormone concentrations in the Gerbil. J. Nut.116: 11651171.

Ham, J. O., Chapman, K. M., Essex-Sorlie, D., Bakhit, R. M., Prabhudesai, M., Winter, L., Erdman, J. W., Jr. and Potter, S. M. (1993). Endocrinological response to soy protein and fiber in mildly hypercholesterolemic men. Nutr.Res.13: 873-884.

Huff, M. W. \&.Carroll, K. K. 1980. Effects of dietary protein on turnover, oxidation, and absorption of cholesterol, and on steroid excretion in rabbits. J. Lipid Res.21: 546-558.

lauk, L., Galati, E.M., Foreestieri, A.M., Kirjavainen, S. and Trovato, A. (1989). Mucuna pruriens decoction lowers cholesterol and total lipid plasma levels in the rat. Phytother.Res.3: 263-264.

Iyayi, E.A. and Taiwo, V.O.2003.The Effect of Diets Incorporating Mucuna pruriens Seed Meal on the Performance of Laying Hens and Broilers. Trop. subtrop. Agroecosys.1: 239- 246.

Kim, D. N., Lee, K. T., Reiner, J. M. and Thomas, W. A. 1980. Increased steroid excretion in swine fed high-fat, high-cholesterol diet with soy protein. Exp.Mol. Pathol.33: 25-35.

Kirk, E.A., Sutherland, P., Wang, S.A.,Chait, A. and LeBoeuf, R.C. 1998. Dietary isoflavones reduce plasma cholesterol and atherosclerosis in C57BL/6 mice but not LDL receptor-deficient mice. J.Nut.128: 954-959.

Khosla, P., Samman, S. and Carroll, K. 1991. Decreased receptor mediated LDL catabolism in casein-fed rabbits precedes the in crease in plasma cholesterol levels. J.Nut.Biochem.2: 203- 209.

Layrisse, M., Martinez-Torres, C., Mendez-Costellaro, H., Taylor, P., Fossi, M., Lopez de Blanco, M., Landaeta-Jimenez, M., Jaffe, W., Leets, I., Tropper, E., Garcia-Casal, M. and Ramirez, J. (1990). Relationship between iron bioavailability from diets and the prevalence of iron deficiency. Food nut. Bul. 12: 301-309.

Lovati, M. R., Manzoni, C., Agostinelle, P., Ciappellano, S., Mannucci, L. and Sirtori, C. R. 1991. Studies on the mechanism of the cholesterol lowering activity of soy proteins. Nut. Met. Cardiovas.Dis.1: 18-24. 
Lovati, M. R., Manzoni, C., Corsini, A., Granata, A., Frattini, R., Fumagalli, R. and Sirtori, C. R. (1992). Low density lipoprotein receptor activity is modulated by soybean globulins in cell culture. J. Nut. 122: 1971-1978.

Nagata, Y., Ishiwaki, N. and Sugano, M. (1982). Studies on the mechanism of the anti hypercholesterolemia action of soy protein and soy protein-type amino acid mixtures in relation to their casein counterparts in rats. J. Nutr. 112: 16141625.

National Research Council. (1994). Nutrient Requirements of Poultry.10 ${ }^{\text {th }}$ Ed. National Academy Press, Washington, D.C.

Pant, M. C., Uddin, I., Bhardwaj, U. R. and Tewari, R. D. (1968). Blood sugar and total cholesterol lowering effect of Glycine soja, Mucuna pruriens and Dolichos biflorus seed diets in normal fasting albino rats. Ind. J. Med. Res.56: 18081812.

Ravindran, V. and. Ravindran, G. (1988). Nutritional and anti nutritional characteristics of Mucuna (Mucuna utilis) bean seeds. J. Sci. Food Agric.46: 71-79.

Sanchez, A. and Hubbard, R. W. (1991). Plasma amino acids and the insulin/glucagon ratio as an explanation for the dietary protein modulation of atherosclerosis. Med.Hypo. 35:324-329.

SAS Institute. (2000). SAS/ STAT User's Guide. Version 9.5, SAS Institute, Cary, North Carolina, USA.

Scholz-Ahrens, K. E., Hagemeister, H., Unshelm, J., Agergaard, N. and Earth, C. A. (1990). Response of hormones modulating plasma cholesterol to dietary casein or soy protein in minipigs. J.Nut.120:1387-1392.

Sugano, M., Goto, S., Yamada, Y., Yoshida, K., Hashimoto, Y., Matsuo, T. and Kimoto, M.

(1990). Cholesterol lowering activity of various undigested fractions of soya bean protein in rats. J. Nutr.120: 977-985.

Tanaka, K., Aso, B. and.Sugano, M. (1984). Biliary steroid excretion in rats fed soybean protein and casein or their amino acid mix tures. J.Nut.114: 26-32.

Van der Meer, R., de Vries, H. T. and van Tinlelen, G. (1988). The phosphorylation state of casein and the species-dependency of its hypercholesterolemic effect. Brit. J.Nut.59: 467-473. 